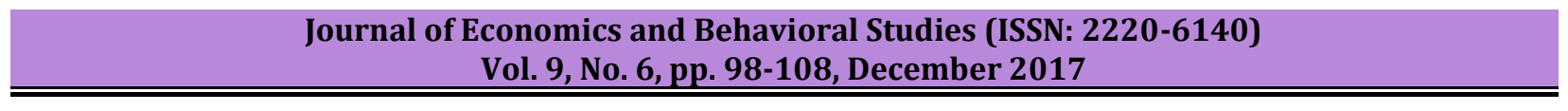

\title{
Strategic Planning and Performance of Nigerian SMEs: The Moderating Role of Entrepreneurial Characteristics
}

\author{
Makinde Olubisi G., AsikhiaOlalekan U. \\ Department of Business Administration and Marketing, Babcock University, Nigeria \\ makindeo@babcock.edu.ng, asikhiao@babcock.edu.ng
}

\begin{abstract}
Studies that considered the moderating effect of entrepreneurial characteristics on the relationship between strategic planning and performance of SMEs are few. This research is aimed at investigating the relationship between strategic planning and SME performance while also considering the moderating effect of entrepreneurial characteristics on the relationship between these two variables. The study employed the use of survey research design using the owners/managers of 4,535 SMEs registered with SMEDAN as the target population. Correlation analysis was used to establish the extent of the relationship between strategic planning and performance of SMEs while hierarchical regression analysis was used to establish the moderating effect of entrepreneur characteristics on the relationship. Findings showed that there exist statistically significant positive relationship between strategic planning and performance of SMEs in Lagos State, the study also indicated that entrepreneurial characteristics significantly moderates the relationship between strategic planning and performance of SMEs. The study concluded that entrepreneurial characteristics being exhibited influenced the performance of the business. Policy implications and recommendations were made.
\end{abstract}

Keywords: Strategic Planning, Performance, SMEs, Economic Development, Entrepreneurial Characteristics

\section{Introduction}

Economic development has been ascribed to an effervescent Small and Medium Enterprises (SMEs) (Muritala, Awolaja, and Bako, 2012). Most developed economies of the world have relied more on the development of the SME sector in order to achieve and sustain their economies. Safiriyu and Njogoh (2012) opine in their study that SMEs are very critical in the attainment of economic prosperity while Muritala, Awolaja and Bako (2012) assert that there is connection between the importance given to the SMEs and economic growth and development of a country. Many developed economies have ascribed their advancement to a successful and virile SME sector and the developing economies also considered the sector as the "engine for economic development" (Ale, Ahmed and Taha, 2010).The small and medium scale enterprises are contributing to the growth and development of several countries in terms of employment generation which in turn leads to poverty reduction and growth in the Gross Domestic Product (GDP) as well as increase in export which forms the backbone of economic and industrial development which have contributed to the economic success of Asian countries (Onugu, 2005; Ayozie, 2011; Agu \& Nwachukwu, 2012; Idowu, 2012; Gbandi \& Amissah, 2014).

The Central Bank of Nigeria (CBN, 2011) reports that the SME sector in India is responsible for up to 39\% of manufacturing activities and 33\% of total exports of that country. Moreover, the report of the Small and Medium Enterprises Development Agency of Nigeria (SMEDAN) published by the National Technical Working Group (2009) indicated that SMEs in the United Kingdom contribute up to 54\% to employment generation and poverty eradication. Similarly, Belgium and Ireland recorded $66.6 \%$ and $66.5 \%$ respectively. Developing economies such as China and South Korea were also able to accomplish up to $75 \%$ and $70 \%$ respectively while Nigeria has only been able to attain 10\%.Oni and Daniyan (2012) note that there has been a move from capital intensive and large scale industrial projects to small and medium scale enterprises since the introduction of the 1981 Economic Reform in Nigeria because this is considered as a catalyst that will propel the economy towards development. In like manner, Ojo (2009) states that one of the responses to the challenges of development in developing economies like Nigeria is the success of the SME sector.There has been a drop in job availability in the country and those that are employed are having challenges keeping their employment therefore there is need for vibrant Small and Medium Scale Enterprises (SMEs) which have become means of guaranteeing "self-independence, employment creation, import substitution, effective and efficient utilization of local raw materials" (Oni and Daniyan, 2012). Agwu and Emeti, (2014) state that there is high level of unemployment in the country which could be attributed to the poor performance of SMEs in 
employment generation. Moreover, government at various levels have all focused on the development SMEs in order to improve the socio-economic development through alleviating poverty, employment generation, enhancing human development, and improving social welfare of the people by formulating policies that will ensure the growth and performance of SMEs (Akingunola, 2011).

The Federal government of Nigeria has supported the SMEs with special policies and funding but despite the various government intervention policies and funding, there are still challenges of survival. As such, the desired impact to the economic development of the country is still farfetched which suggests that there are other factors responsible for the failures other than finance. It was therefore postulated that other endogenous factors may be responsible for the failure. It has further been indicated that in strategic planning research and practice, attention to environmental influences (moderating factors) seem to have been ignored (Drago and Clements, 1999; Asikhia, 2010; Islam, Khan, Obaidullah and Alam, 2011; Dandira, 2011; Nooraie, 2012). One of such factors, identified in this study is entrepreneurial characteristics. This seems to support assertions that performance lapses among SMEs are due to entrepreneurs' inabilities to envisage and factor into their planning processes the role of some contextual variables and the influence that strategic planning has on organizational performance. Is it possible then to conclude that a contextual factor such as the entrepreneurial characteristics can influence the strategic planning and performance relationship of SMEs? In line with this observation while considering the work of previous researchers, this research aims to study the influence of moderator's factors (entrepreneurship characteristics) on the contribution of strategic planning to SMEs performance. It attempts to answer the following question: "Do entrepreneurship characteristics influence the contribution of the strategic planning to SMEs performance?" The essential motivation of this research is summed up in the researchers' desire to identify, describe and measure the impact of strategic planning on SMEs performance taking into account the effect of entrepreneurship characteristics such as entrepreneurial orientation and managerial attitude, in the context of SME sector in Lagos, Nigeria. The specific objectives of this research are to: determine the level of adoption of strategic planning by SMEs in Lagos State, Nigeria. Secondly, to evaluate the strength of the entrepreneur characteristics on the strategic planning-performance link in the SME sector in Lagos, Nigeria.

\section{Literature Review}

Strategic Planning and Performance of SMEs: Performance is the measure of an organization's judicious use and management of resources to add value to customers and other stakeholders (Wu, 2009). It is also described as how well an organization has been managed and the value (Laitinen, 2002 in 0'Regan, \& Ghobadian, 2007). It is the ability of an object to produce the desired results in a dimension that meets the expectation in relation to a target (O'Regan and Ghobadian, 2007). Yusuff, Olagbemi and Atere (n.d.) posit that firm's performance is multifaceted and is categorized by the firms' ability to create adequate results and activities. It was concluded that performance can include "survival, profit, return on investment, sales growth and number of employees". Adeoye and Elegunde (2012) categorize performance of an organization into financial performance, product or market performance and shareholders' return. Performance of an organization can also be described as an approach used in assessing the progress made towards achievement of goals, recognizing and adjusting factors which will limit the development of the organization in the environment (Adeoye \& Elegunde, 2012). An organization is said to be effective if it makes use of its resources to attain high level of performance (Adeleke, Ogundele and Oyenuga, 2008). It was also postulated that a business organization can be said to be effective if it achieves the set goals of sales or market share which depends on how efficient the organization is. Performance is therefore conceived according to Adeleke, Ogundele and Oyenuga (2008), as a "set of processes for establishing shared understanding about what is to be achieved and of managing and developing people in a way which increases the probability that it will be achieved in the short and long term".

The use of strategic planning has been adopted by the management world as a tool for achieving organizational performance. Various studies have been conducted on the relationship between strategic planning and organizational performance in different economic settings (Grant, 2003; Glaister, Dincer, Tatglu, Demirbag and Zaim, 2008; Efendioglu and Karabult, 2010; Arasa and K'Obonyo, 2012). Organizations have adopted the use of strategic planning to identify the strategies that have resulted in increased outcomes and competitive advantage. According to Ansoff (1965) the key to an organization's successful acquisition, 
distribution and processing of resources is the use of strategy. Strategic planning benefits an organization by improving its performance and enabling it to cope with environmental challenges, assists with change management and helps an organization to resolve human resources challenges. Adeleke, Ogundele and Oyenuga (2008), posit that organizations use strategic planning to predict changes in the environment in order to forestall any unforeseen circumstances. Silverman (2000) concludes that the performance of an organization depends on proper implementation of strategic planning. Every organization desires success and high performance hence there is need to plan strategically to ensure the realization of such success. Based on the discussions above, the following hypothesis is hereby formulated:

Hypothesis 1: there is no significant relationship between strategic planning and SMEs performance in Lagos State.

The Moderation Effects of Entrepreneurial Characteristics: As implied, entrepreneurial characteristics in this research paper focuses on two major areas of the SMEs- entrepreneurial orientation and managerial attitude. Arguably, entrepreneurial orientation and managerial attitude are indispensible factors that shapes and determines the success or failure of a firm or business activities (Wiklund \& Shephard, 2003). Thus, they determine the effectiveness of the firm performance and business activities. According to Wiklund and Shephard (2003, referring to Hamel, 2000), entrepreneurial orientation (E0) has positive performance implication for the firm. The authors indicated that when product and business lifecycles are shortened, profitability becomes uncertain. Previous studies have revealed that entrepreneurial characteristics and managerial attitude are important factors to consider when talking about SME performance (Asikhia, 2010; Covin, Green \& Slevin, 2006; Wiklund\& Shephard, 2003). It was posited that the attitude of the manager and the orientation he has as an entrepreneur will affect his behaviour. Aziz, Mahmood, Abdullah and Tajudin, (2013) posit that the entrepreneurial orientation and performance are closely related. Chakravarty (1982) explores the entrepreneurial strategy-making and its relationship with performance and there exists a relationship between the two concepts. Similarly, Aziz, Mahmood, Abdullah and Tajudin, (2013) also confirm that entrepreneurial orientation has effect of the overall firm performance. While Asikhia (2010) also confirm that there is a relationship between managerial attitude and SME performance. Wiklund and Shephard (2003) examine knowledge-based resources, entrepreneurial orientation, and the performance of small and medium-sized businesses. The study found that entrepreneurial orientation moderates the relationship between knowledge based-resources and firm performance. This finding implies that the willingness of a firm to be innovative, proactive, and risk taking enhances the positive effects of knowledge-based resources on performance. Hence, it is assumed that entrepreneurial orientation and managerial attitude would play significant roles of strengthening and stabilizing the relationship between strategic planning and firms' performance.From the above discussions, the following hypothesis is being advanced:

Hypothesis 2: There is no significant moderating effect of entrepreneurial characteristics on the relationship between strategic planning and SME performance.

Figure 1: Model of Strategic Planning and Performance

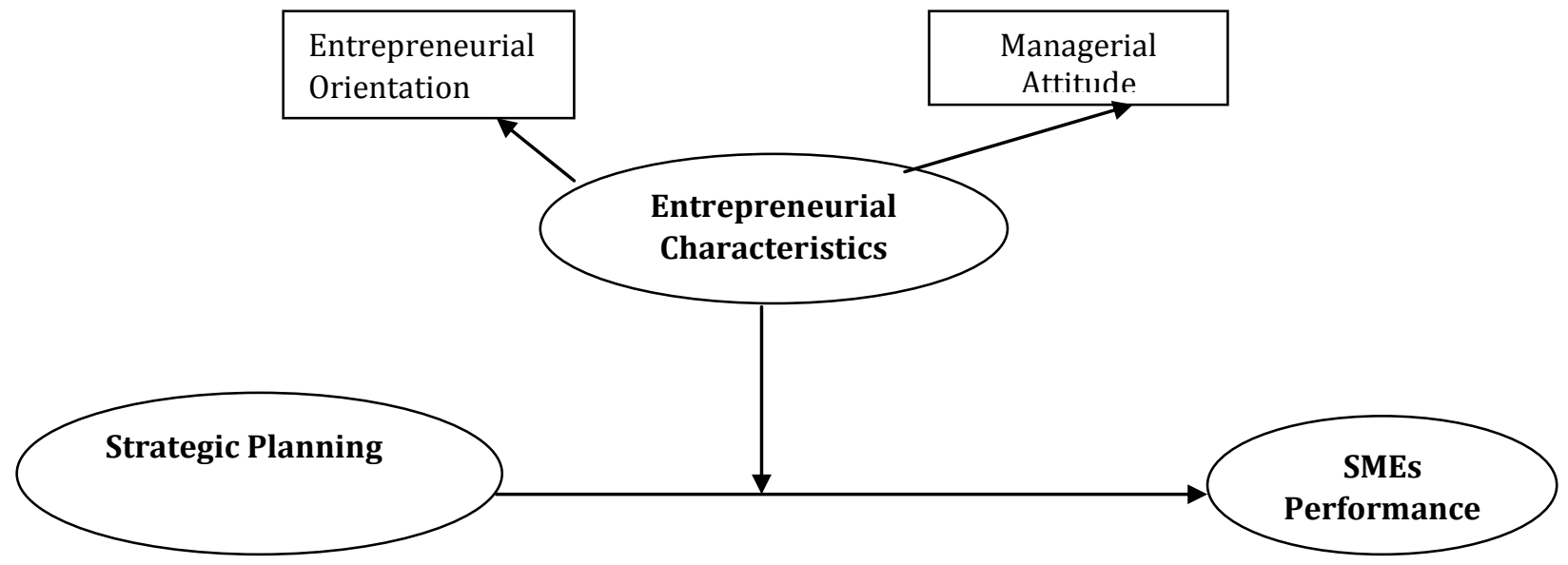

Source: Developed by the Researchers 
Conceptual Framework: In order to attain the objective of the research paper, we propose a conceptual model that focuses on the relationship between all the variables: entrepreneurial characteristics, strategic planning and SMEs performance. Specifically, we wish to test the causal link between the SMEs performance in the study area and strategic planning, taking into consideration the entrepreneurial orientation and managerial behaviour.

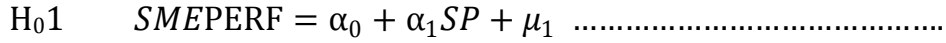

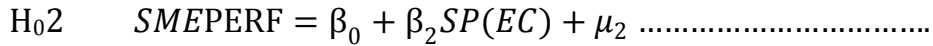

\section{Methodology}

Research Context: The study investigated the factors responsible for the failure of SMEs in Nigeria despite the different policies of Government over the years and the special funding options that have been provided for this sector of the economy. Despite all efforts of government, it has been postulated that up to $85 \%$ of SMEs die before the tenth year of existence (NTWG, 2009). While the report of the NTWG (2009) identified external factors responsible for the failure of the sector, other internal factors were also identified. Most studies have focused on the external factors while the internal factors are yet to be investigated fully. This study explored the internal factors by studying the use of strategic planning as it relates to the performance of the SMEs while also considering the moderating effect of entrepreneurial characteristics of the owners who are in most cases the managers of these SMEs.

Sample and Data Collection: This study adopted the descriptive survey research design. The population of the study comprised of the Small and Medium Scale Enterprises (SMEs) operating in Lagos State registered with the Small and Medium Enterprises Development Agency of Nigeria (SMEDAN) which was 4,535 as at May, 2012. A sample size of 520 was selected for the study using the Cochran (1977) standard method of randomization. The sample was drawn from the five divisions of Lagos which are Badagary, Epe, Ikeja, Ikorodu and Lagos Island. The data for the study was collected through a well structured questionnaire. The questionnaire was measured by six-point Likert type scale ranging from 1 (strongly disagree) to value 6 (strongly agree) used throughout the questionnaire. Thirty copies of the questionnaire were pre-tested among randomly selected SMEs in Ogun State to ensure the validity and reliability of the instrument. The Cronbach-alpha method was used to determine the internal consistency of the instrument and the following values were obtained: Strategic Planning [formulation (0.898), implementation (0.753) \& control (0.711)], Enterptreneural Characteristics [managerial attitude (0.781), entrepreneurial orientation (0.726)], and SME performance [(0.887) for SME performance scale. The values surpassed the minimum acceptable level of 0.70 suggested by Nunally, (1978). Therefore, it shows that the items used in the construct are reliable and consistent. The original users of the measuring instruments established the validity. However, Average Variance Extracted (AVE) $>0.5$ were treated as an additional evidence of convergent validity, the construct validity of all variables involved in the study were therefore ascertained. The copies of the questionnaire were taken to the leaders of the various associations, unions and cooperative societies for easy administration and collection.The leaders worked with the research assistants to help in distributing the copies to the members during their monthly meetings. Out of the 520 copies of the questionnaire administered, 482 questionnaires were retrieved representing $92.7 \%$ return rate. The collected data were all processed by using Statistical Package for Social Science (SPSS) computer software program. Data was analyzed using descriptive statistics and the hypotheses were tested by standard hierarchical regression analysis at $5 \%$ significance level.

Measures: The measures of the variables were drawn from existing literature as provided in table 1: 


\begin{tabular}{l} 
Journal of Economics and Behavioral Studies (ISSN: 2220-6140) \\
Vol. 9, No. 6, pp. 98-108, December 2017 \\
\hline \hline
\end{tabular}

Table 1: Sources of Adopted Questionnaire

\begin{tabular}{llll}
\hline Objectives & Variables & Source(s) of Instrument \\
\hline 1 & Strategic planning & $\begin{array}{l}\text { Formulation } \\
\text { Implementation Control }\end{array}$ & Shelette (2002) \\
2 & $\begin{array}{l}\text { Entrepreneurial } \\
\text { Characteristics }\end{array}$ & $\begin{array}{l}\text { Managerial Attitude } \\
\text { Entrepreneurial Orientation }\end{array}$ & $\begin{array}{l}\text { Asikhia, (2010) } \\
\text { Covin, Green and Slovin } \\
\text { (2006) }\end{array}$ \\
3 & SME Performance & $\begin{array}{l}\text { Sustainable Competitive Advantage } \\
\text { Sales Growth Profitability }\end{array}$ & Asikhia, 2010 \\
\hline
\end{tabular}

\section{Results and Discussion}

Table 2 reveals the demographic characteristics of the owner/managers of SMEs

Table 2: Demographic Profile of the Respondents

\begin{tabular}{lll}
\hline Category & Frequency & Percentage \\
\hline Age: & 215 & \\
$18-30$ & 206 & 44.6 \\
$31-44$ & 24 & 42.7 \\
$45-59$ & 37 & 5.0 \\
60 and Above & 482 & 7.7 \\
Total & & 100.0 \\
Gender & 361 & \\
Male & 121 & 74.9 \\
Female & 482 & 25.1 \\
Total & & 100.0 \\
Educational Qualification & 155 & \\
Diploma & 131 & 32.2 \\
First Degree & 30 & 27.2 \\
Second Degree & 71 & 6.2 \\
Doctoral & 95 & 14.7 \\
Others & 482 & 19.7 \\
Total & & 100.0 \\
Working Experience & 254 & \\
0-5 years & 142 & 52.7 \\
6-9 years & 26 & 29.5 \\
10-14 years & 60 & 5.4 \\
15 and Above & 482 & 12.4 \\
Total & & 100.0 \\
\hline
\end{tabular}

Source: Field Survey, 2015

Table 2 presents the demographic information of the owner/managers of the SMEs surveyed. Majority of the respondents - 445 representing $92.3 \%$ of the valid sample size were within the age bracket of 18-59 years. Majority of the respondents (361 in all or 74.9\%) who participated in the survey were male entrepreneurs, managers and CEOs while 121 (25.1\%) were female. A total of 155 respondents (32.2\%) had diploma, followed by $131(27.2 \%)$ with first degree certificate. As regards their years of working experience, majority of the respondents (52.7\%) in the participating SMEs surveyed had prior experience in their fields of endeavor. A large percentage (45.2\%) of the firms or participating SMEs surveyed had been in existence in Nigeria for between 4 to 10 years. Most of the participating SMEs (46.15\%) have less than five employees in their business. This confirmed that all the respondents work in firms that actually fall within the established category of small and medium enterprises (less than 199 employees) as stipulated by the National Policy on 
Micro, Small and Medium Enterprises. Lastly, a majority of the participating SMEs (41.1\%) were in the manufacturing sector.

Hypothesis Testing: To test hypotheses, regression analysis was used to analyze the relationship between the strategic planning and SMEs performance. The coefficient of correlation and coefficient of determination $\left(R^{2}\right)$ are indicated in table 3. The coefficient of determination $\left(R^{2}\right)$ indicates the goodness and fitness of the model.

Hypothesis $1\left(\mathbf{H}_{\mathbf{0}}\right)$ : there is no significant relationship between strategic planning and SMEs performance in Lagos State.

Table 3: Moderated Multiple Regression Model Summary for Entrepreneurial Characteristics

\begin{tabular}{llllllll}
\hline Model & $\mathbf{R}$ & $\mathbf{R}$ Square & $\begin{array}{l}\text { Adjusted } \\
\text { Square }\end{array}$ & $\begin{array}{l}\text { Std. Error of ANOVA } \\
\text { the Estimate }\end{array}$ & Sig. \\
\hline 1 & $.817^{\mathrm{a}}$ & .667 & .665 & 5.56559 & 147.301 & .000 \\
\hline
\end{tabular}

Dependent Variable: SMEs Performance

Source: Researcher's Field Survey from SPSS output, 2015

Table 3indicates the model summary of the hierarchical regression equation that predicted the value of SME performance reacting to strategic planning and entrepreneurial characteristics. The results showed that SMEs performance has a significant relationship with strategic planning with correlation valueof $(\mathrm{r}=0.817, \mathrm{p}$ $=0.000,<0.05$ alpha level). The $\mathrm{R}^{2}$ which is the proportion of the variation in the dependent variable that can be attributed to the independent variableshowed that $66.7 \%$ of the variance in SME performance appears accounted for by Strategic planning.The results indicated that strategic planning contributed significant amount of variance in SMEs performance in Lagos State. The significant relationship at $\mathrm{p}<0.05$ level provides empirical support for $\mathrm{H} 1$ that significant relationship exists between Strategic planning and SMEs performance. Therefore, the null hypothesis which states that there is a significant relationship between strategic planning and SMEs performance in Lagos State, is rejected.

Hypothesis 2: There is no significant moderating effect of entrepreneurial characteristics on the relationship between strategic planning and SME performance.

The hypothesis was tested using the standard hierarchical regression models of Ordinary Least Method (OLS) for strategic planning, entrepreneurial characteristics and SME performance. Hierarchical regression allows for an assessment of the incremental increase in the explained variance of a dependent variable that is explained by the successive addition of sets of independent variables where the variance explained by previously entered variables is partialled out. This is to enable the researcher to determine whether entrepreneurial characteristics moderate the relationship between strategic planning and organization performance of SMEs selected in Lagos State, Nigeria.Analyses were made following the steps suggested by Baron and Kenny (1986) in conducting moderation test. In testing the interaction effects of entrepreneurial characteristics on the relationship between strategic planning and SME performance, the problem of multicollinearity had to be dealt with. Multicollinearity which is multi correlations with sufficient magnitude and has the potential to adversely affect regression estimates (Fox, 1992). According to Aiken and West (1991), multicollinearity can inflate the value of $\mathrm{R}^{2}$ (the proportional variation in the dependent variable which can be explained by independent variable) even when none of the beta weights are statistically significant. Multicollinearity can also produce bizarre beta weight estimates, and may lead to enormous changes in the model whenever a predictor variable is added or removed. According to Fox (1992), multicollinearity is better measured using tolerance and Variance Inflation Factor (VIF). Tolerance is the percentage of variance in the independent variable that is not accounted for by other independent variables, while Variance Inflation Factor is the reciprocal of tolerance. It was further pointed out that VIF of 3 or greater are often cited as indicative of problematic collinearity and have the potential to adversely affect regression estimates. A test for multicollinearity revealed that strategic planning has low level of multicollinearity with entrepreneurial characteristics (VIF of 1.490). 


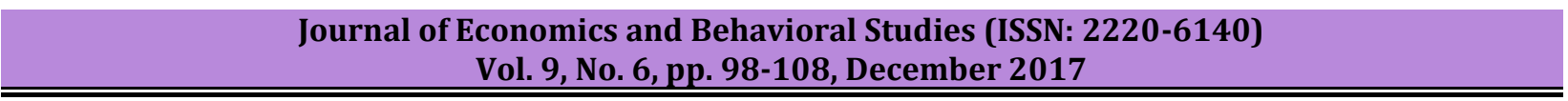

Table 4: Multicollinearity with entrepreneurial characteristics

\begin{tabular}{lll}
\hline Model & \multicolumn{2}{c}{ Collinearity Statistics } \\
& Tolerance & VIF \\
\hline Strategic Planning* Entrepreneurial characteristics & 0.6711 & 1.490 \\
Strategic Planning*Entrepreneurial characteristics Centered & 0.721 & 1.386 \\
\hline
\end{tabular}

Source: Researcher's Field Survey from SPSS output, 2015

To avoid any problem associated with multicollinearity with interaction term, strategic planning and entrepreneurial characteristics variables were subtracted from their averages (centered) before a regression analysis was run. While analyzing the transformed scores, the effects of other variables were considered to be null. According to Baron and Kenny (1986), even if the basic effect in the $1^{\text {st }}$ and $2^{\text {nd }}$ steps is found to be insignificant, but the interaction variable is found to be significant, it is sufficient for assessment of moderation effect.

Table 4: Means of the variables

\begin{tabular}{lllll}
\hline & N & Mean & Std. Deviation & Variance \\
\hline Strategic Planning & 482 & 56.1870 & 7.05826 & 0.8769 \\
Entrepreneurial characteristics & 482 & 49.5496 & 8.12439 & 0.9864 \\
SMEs Performance & 482 & 81.4437 & 10.68043 & 0.6904 \\
Valid N (listwise) & 482 & & & \\
\hline
\end{tabular}

Source: Researcher's Field Survey from SPSS output, 2015

The SPSS syntax was used to determine the means, center the variables and to generate an interaction term. From table 4, SMEs Performance had the highest mean of 81.4437, followed by strategic planning at a mean of 56.1870. Entrepreneurial characteristics had the least mean of 49.5496. Moderation analysis was undertaken using regression because both the independent variable and moderating variable had a scale level data (Faraway, 2002).

Table 5: Model Summary of Strategic Planning, Entrepreneurial Characteristics, \& SMEs Performance

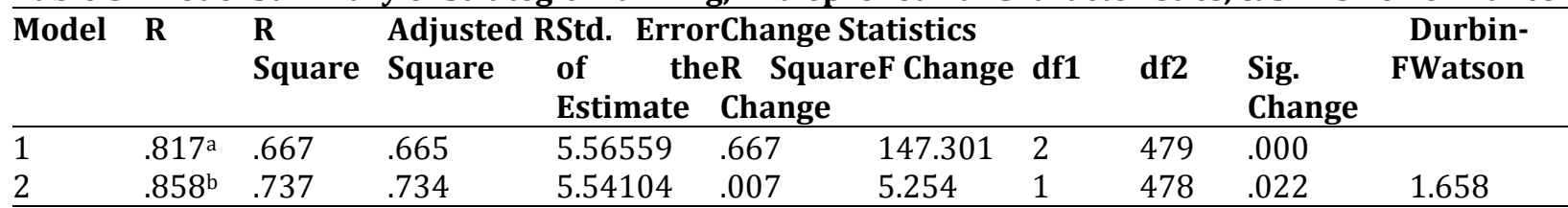

a. Predictors: (Constant), Entrepreneurial Characteristics, Strategic Planning

b. Predictors: (Constant), Entrepreneurial Characteristics, Strategic Planning, Strategic Planning*Entrepreneurial Characteristics

c. Dependent Variable: SMEs Performance

From Table $5, \Delta \mathrm{R}^{2}=0.007, \Delta \mathrm{F}(1,478)=5.254, \mathrm{p}=0.022$. Because $\mathrm{p}<0.05$, the interaction term is significant, therefore entrepreneurial characteristics has a moderating effects on the relationship that exists between strategic planning and SMEs performance. Hypothesis two, which states that entrepreneurial characteristics has no significant moderating effect on the relationships between strategic planning and the SMEs performance in Lagos State is therefore not supported, and thus rejected. 
Journal of Economics and Behavioral Studies (ISSN: 2220-6140)

Vol. 9, No. 6, pp. 98-108, December 2017

Table 6: Coefficient of Strategic Planning, EntrepreneurialCharacteristics, and SMEs Performance

\begin{tabular}{|c|c|c|c|c|}
\hline $\begin{array}{l}\text { Dependent } \\
\text { Variable }\end{array}$ & $\begin{array}{c}\text { Independent and } \\
\text { Moderating variables, and } \\
\text { interaction effects }\end{array}$ & $\begin{array}{l}\text { Standardized } \\
\text { Coefficients }\end{array}$ & t-test & Significance \\
\hline SMEs & (Constant) & 56.187 & 221.640 & .000 \\
\hline \multirow{6}{*}{ Performance } & Strategic Planning & .793 & 7.632 & .000 \\
\hline & Entrepreneurial & .452 & 3.536 & .000 \\
\hline & $\begin{array}{l}\text { Characteristics } \\
\text { (Constant) }\end{array}$ & 56465 & & (000 \\
\hline & Strategic Planning & .643 & 5.555 & .000 \\
\hline & Entrepreneurial & .553 & 4.585 & .000 \\
\hline & $\begin{array}{l}\text { Characteristics } \\
\text { Strategic } \\
\text { Planning*Entrepreneurial } \\
\text { Characteristics }\end{array}$ & .403 & 6.292 & .022 \\
\hline
\end{tabular}

Source: Researcher's Field Survey from SPSS output, 2015

The results in Table 6 show the moderator role of Entrepreneurial Characteristics in the relationship between strategic planning and SME performance. Indeed, strategic planning has a positive effect on the SMEs performance $(\beta=.793, t=7.632, p=.0001)$. Entrepreneurial Characteristics also has a direct effect on the SMEs performance $(\beta=.452, \mathrm{t}=3.536, \mathrm{p}=.0001)$. The product or interaction (Planning*Entrepreneurial Characteristics) has a strong positive effect on the SMEs performance $(\beta=.403, t=6.292)$. The result shows the presence of moderating effect of entrepreneurial characteristics on the relationship between strategic planning and SME performance. Therefore, the null hypothesis, which states that there is no significant moderating effect of entrepreneurial characteristics on the relationship between strategic planning and SME performance', is rejected. Hence, entrepreneurial characteristics have a significant moderating effect on the relationship between strategic planning and SME performance in Lagos State.

Discussions: This section discusses the result and findings derived from the data analysis. The main purpose of this study was to examine the strength of the entrepreneur characteristics on the strategic planningperformance link in SMEs in Lagos State, Nigeria. The result of the study shows that there is a high and significant relationship between strategic planning and SMEs performance, where $(r=.817, p<.05)$. This means that SMEs that practice and use strategic planning have high performance than SMEs that do not practice strategic planning. The result supported the findings of Pushpakumari and Toshimitsu (2009) who discovered that strategy and performance of manufacturing SMEs in Japan and Sri Lanka are related. The study of Babsundaram (2009) also reports that strategic planning contributes to the relationship with the overall performance of small business. Furthermore, the study of Awino (2013) supports the findings since the result revealed that strategic planning is a means of achieving competitive advantage in the ICT industry of the SME sector in Kenya. The finding of the study suggests that strategic planning is important for business to succeed.

The result of the moderated (hierarchical) regression analysis indicates that the product or interaction of strategic planning and entrepreneurial characteristics has a strong positive effect on the SMEs performance, where $(\beta=.403, t=6.292, p<.05)$. It shows the presence of moderating effect of entrepreneurial characteristics on the relationship between strategic planning and SME performance. The finding further suggests that SMEs with good entrepreneurial characteristics tend to do better than SMEs with poor entrepreneurial characteristics. The studies conducted by Chakravarty (1982), Asikhia (2010) and Aziz, Mahmood, Abdullah and Tajudin, (2013) do support this finding that entrepreneurial characteristics moderate the relationship between strategic planning and SME performance. Furthermore, the finding is supported by the studies of Wiklund and Shephard (2003), that the willingness of a firm to be innovative, proactive, and take risks enhances the positive effects of the bundle of knowledge-based resources on performance. 


\section{Conclusion}

The study examined the influence of entrepreneurial characteristics (moderating variable) on the relationship between strategic planning and SME performance in Lagos State, Nigeria. Furthermore, the relationship between strategic planning and SME performance was also examined. Even though the success of every developed economy has been traced to the success in the small and medium enterprises sector, little research seems to have been conducted on the relationship between strategic planning and performance in the SME sector in Lagos State. Therefore, the study investigated the relationship between the two variables and also considered the moderating roles of some entrepreneurial characteristics on the relationship between the strategic planning and SMEs performance in Lagos State. It was discovered that strategic planning positively affects the performance of SMEs and the entrepreneurial characteristics also affect the relationship that exists between the variables. When entrepreneurs exhibit the right characteristics, that is having the right orientation and managerial attitude combined with effective strategic planning, performance will be positively affected and the SME sector will be able to contribute significantly to economic development in Lagos State, Nigeria.

Recommendations: The findings of the study revealed that entrepreneurial characteristics positively influence the relationship between the use of strategic planning and performance of SMEs, it is therefore recommended that managers and owners of SMEs should be conscious of the kind of attitude being exhibited at the workplace. Since entrepreneurial orientation involves risk taking, innovativeness and proactiveness, they should acquire this orientation in order to be able to achieve their desired objectives. Furthermore, the Small and Medium Enterprises in Lagos State, Nigeria should embrace the use of strategic planning as a tool and a concept to be used in achieving organizational performance. The owner/managers of SMEs should look inwards to develop the right managerial attitude and have the right orientation rather than continue to hinge the poor performance of the sector on external factors. The results from this study could form the basis for SME operators to re-evaluate their internal competencies in order to achieve greater performance.

Limitations and Further Research: Although this research produced meaningful results, it was also subject to certain limitations which in turn provide avenues for further research. For instance, the study only treated the moderating variables in relation to the owners and managers of SMEs. There is a possibility that the variables considered can also be related to the workers in these sectors. Moreover, there is also the possibility that other internal factors can also affect strategic planning and performance. Future researchers may consider other moderating variables that could also affect the strategic planning-performance relationship. Other external variables could also be used as moderators between strategic planning and SME performance. Further limitations of the study included using qualitative or non-financial performance measures of SMEs. Future research could examine other performance measures such as the financial measures to know how strategic planning could influence those measures.

\section{References}

Adeleke, A., Ogundele, O. J. K. \& Oyenuga, O. O. (2008). Business policy and strategy. (2 ${ }^{\text {nded). Lagos: Concept }}$ Publications Limited.

Adeoye, A. O. \& Elegunde, A. F. (2012). Impacts of external business environment on organizational performance in the food and beverage industry in Nigeria. British Journal Publishing, 6(2), 194 -200. Retrieved from http://www.bjournal.co.uk/BJASS.aspx

Agwu, M. O. \& Emeti, C. I. (2014). Issues, challenges and prospects of small and medium scale enterprises (SMEs) in Port-Harcourt city, Nigeria. European Journal of Sustainable Development, 3(1), 101-114. Retrieved from http://www.ecsdev.org/images/V3N1/agwu\%20101-114.pdf

Agu, A. O. \& Nwachukwu, C. (2012). The role of entrepreneurship in economic development: The Nigerian perspective. European Journal of Business and Management 4(8), 95-105.

Aiken, L. S. \& West, S. G. (1991). Multiple regression: Testing and interpreting interactions. Newbury Park: Sage

Akingunola, R. O. (2011). Small and medium scale enterprises and economic growth in Nigeria: An assessment of financing options. Pakistan Journal of Business and Economic Review, 2(1), 78-97. 
Ale, E., Ahmed, S. \& Taha, Z. (2010). Critical factors for new product developments in SMEs virtual team. African Journal of Business Management, 4(11), 2247-2257. Retrieved from http://www.academicjournals.org/AJBM/abstracts/abs

Ansoff, H. I. (1965). The state of practice in planning systems. Sloan management Review, 78(2), 1-24

Arasa, R. \& K'Obonyo, P. (2012). The relationship between strategic planning and firm performance. International Journal of Humanities and Social Science, 2(22). Retrieved from http://erepository.uonbi.ac.ke/bitstream/handle/123456789/19501/The\%20Relationship\%20bet ween $\% 20$ Strategic\%20Planning\%20and\%20Firm\%20Performance.pdf?sequence $=1$

Asikhia, O. U. (2010). Customer orientation and firm performance among Nigerian small and medium scale businesses. International Journal of Marketing Studies, 2(1), 197 - 212.

Ayozie, D. O. (2011). The role of small scale industry in national development in Nigeria. Universal Journal ofManagement and Social Sciences, 1(1), $23-41$.

Aziz, R. A., Mahmood, R., Abdullah, M. H. \& Tajudin, A. (2013). The mediating effects of entrepreneurial orientation on the relationship between leadership styles and performance of SMEs in Malaysia. The 2nd IBSM, International Conference on Business and Management, 2 - 4 October 2013, Chiang Mai Bangkok.

Awino, Z. B. (2013). Strategic planning and competitive advantage of ICT small and medium enterprises in Kenya. Business and Management Horizons, 1(1), 191 - 204.

Balasundaram, N. (2009). Incidence of strategic planning in small business: an overview. Buletinul Universitatu Petrol -Gaze din Ploiesti, IXI(3), 11-17

Baron, R. M.\& Kenny, D. A. (1986). The moderator-mediator variable distinction in social psychological research: Conceptual, strategic and statistical considerations. Journal of Personality and Social Psychology, 51, 1173-1182

Chakravarty, B. S. (1982). Adaptation: A promising metaphor for strategic management. The Academy of Management Review, 7(1), 35-44. Retrieved from http://www.jstor.org/stable/257246

Cochran, W. G. (1977). Sampling techniques ( $3^{\text {rd }}$ ed.). New York: John Wiley \& Sons

Central Bank of Nigeria (2011). SMEs financing in Nigeria. Retrieved from http://www.cenbank.org

Covin, J. G., Green, K. I. M. \& Slevin, D. P. (2006). Strategic process effects on the entrepreneurial orientation sales growth rate relationship. EntrepreneurshipTheory and Practice, 30(1), 57-81

Dandira, M. (2011). Involvement of implementers: missing element in strategy formulation. Business Strategy Series, 12 (1), 30-34.

Drago, W. A. \& Clements, C. (1999). Leadership characteristics and strategic planning. Management Research News, 22(1), 11 - 18. From http://dx.doi.org/10.1108/01409179910781599

Efendioglu, A. M. \& Karabulut, A. T. (2010). Impact of strategic planning on financial performance of companies in Turkey. International Journal of Business and Management, 5(4), 3 - 12. Retrieved from www.ccsenet.org/ijbm

Faraway, J. J. (2002). Practical regression and ANOVA using R. Unpublished manuscript, Retrieved on $13^{\text {th }}$ July, 2017 from https://cran.r-project.org/doc/contrib/Faraway-PRA.pdf

Fox, J. (1992). Generalized collinearity diagnostics. Journal of the American Statistical Association, 87(417), 178-183

Gbandi, E. C. \& Amissah, G. (2014). Financing options for small and medium enterprises in Nigeria. European Scientific Journal, 10(1), 327-340.

Glaister, K. E., Dincer, O., Tatoglu, E., Demirbag, M. \& Zaim, S. (2008). A causal analysis of formal strategic planning and firm performance: Evidence from an emerging country. Management Decision, 46(3), $365-391$.

Grant, R. M. (2003). Strategic planning in a turbulent environment: Evidence from the oil majors. Strategic Management Journal, 24(6), 491-517.

Idowu, A. (2012). Entrepreneurial innovation: Small and medium scale enterprises. Health research and economic development in Nigeria. Research on Humanities and Social Sciences, 2(11), 49 - 55.

Islam, A., Khan, M. A., Obaidullah, A. Z. M. \& Alam, A. S. (2011). Effect of entrepreneur and firm characteristics on the business success of small and medium enterprises (SMEs) in Bangladesh. International Journalof Business and Management, 6(3), 289-299.

Muritala T. A., Awolaja, A. M. \& Bako Y. A. (2012). Impact of small and medium enterprises on economic growth and development. American Journal of Business and Management, 1(1), 18-22. 
National Technical Working Group. (2009). Report of the Vision 2020 National Technical Working Group on Small and Medium Enterprises. Retrieve from http://nationalplanning.gov.ng/images/docsNationalPlans/smallandmediumenterprisesntwgreport. pf.

Nunnally, J. C. (1978). Psychometric theory (2nd Ed.). New York: McGraw-Hill.

Nooraie, M. (2012). Factors influencing strategic decision-making processes. International Journal of Academic Research in Business and Social Sciences, 2(7), 405 - 429.

Ojo, O. (2009). Impact of micro finance on entrepreneurial development: A case of Nigeria. A paper presented at the International Conference on Economic organized by the faculty of Business and Administration, University of Bucharest, Romania, $14^{\text {th }}-15^{\text {th }}, 2009$

Onugu, B. A. N. (2005). Small and medium enterprises (SMEs) in Nigeria: Problems and prospects. (Unpublished doctoral thesis). St. Clements University.

Oni, E. O. \& Daniyan, A. A. (2012). Development of small and medium scale enterprises: The role of government and other financial institutions. Arabian Journal of Business and Management Review (OMAN Chapter), 1(7), 16-29.

O'Regan, N. \& Ghobadian, A. (2007). Formal strategic planning: annual rain dance or wheel of success? Strategic Change, 16(1-2), 11-22.

Pushpakumari M. D. \& Toshimitsu, W. (2009). Do strategies improve SME performance? An empirical analysis of Japan and Sri Lanka. Meijo Asian Research Journal, 1(1), 61 - 75.

Safiriyu, A. M. \& Njogoh, B. O. (2012). Impact of small and medium scale enterprises in the generation of employment in Lagos State. Kuwait Chapter of Arabian Journal of Business and Management Review, 1(11), 107.

Shelette, S. (2002). Formal business planning and small business success: A survey of small businesses with an international focus. Journal of American Academy of Business, 2(1), 42-46.

Silverman, L.L. (2000). Using Real Time Strategic Change for Strategy Implementation. Retrieved from http://www.partnersforprogress.com/Articles/LargeGroupInterventions.pdf

Wiklund, J. \& Shepherd, D. (2003). Knowledge-based resources, entrepreneurial orientation, and the performance of small and medium-sized businesses. Strategic management journal, 24(13), 13071314.

Wu A. D. (2009). Measuring Performance in small and medium enterprise in the Information and Communication Technology industries. (Unpublished doctoral thesis), RMIT University

Yusuff, O. S., Olagbemi, A. A. \& Atere, A. A. (n.d). Factors affecting small-scale business performance in informal economy in Lagos State-Nigeria: A gendered based analysis. Retrieved on March 21. 2013 from www.ilo.org/public/eng;ish/iira/documents.pdf. 